\title{
Comparison of biochar properties from 5 kinds of halophyte produced by slow pyrolysis at $500^{\circ} \mathrm{C}$
}

\author{
Hongyang Xiao ${ }^{1}$ Q Qimei $\mathrm{Lin}^{1}\left[\mathrm{C} \cdot\right.$ Guitong $\mathrm{Li}^{1} \cdot$ Xiaorong Zhao ${ }^{1} \cdot$ Jianzhong $\mathrm{Li}^{2} \cdot$ Erzhen $\mathrm{Li}^{2}$
}

Received: 29 June 2021 / Accepted: 23 January 2022

(c) The Author(s) 2022

\begin{abstract}
Glycophyte biomass-derived biochars are currently concerned in most studies. However, little attention is given to the characteristics of halophyte-derived biochars. In this study, five typical halophytes of euhalophytes (Suaeda altissima, Suaeda salsa, and Kalidium foliatum), recretohalophytes (Phragmites australis), and pseudohalophytes (Tamarix chinensis) which are widely distributed in the arid and semiarid regions of northwestern China were selected for producing biochars with a slow pyrolysis process at $500{ }^{\circ} \mathrm{C}$ for $1 \mathrm{~h}$. The harvested biochars were characterized in elemental content, pores, surface area, and surface charges, and then their potential value as a soil conditioner was evaluated. The results showed that the halophytederived biochars had variable ash and $\mathrm{Na}^{+}$contents, ranging from 7.26 to $23.64 \%$ and 1.06 to $33.93 \mathrm{~g} \mathrm{~kg}^{-1}$ respectively. The EC value of the biochars ranged from 1.76 to $23.45 \mathrm{mS} \mathrm{cm}^{-1}$. The biochar derived from Suaeda altissima had a very low specific surface area (SSA), $3.50 \mathrm{~m}^{2} \mathrm{~g}^{-1}$, while that derived from Phragmites australis $\left(\mathrm{B}_{\mathrm{PA}}\right.$ ) had a very high SSA, 344.02 $\mathrm{m}^{2} \mathrm{~g}^{-1}$. All the biochars carried both positive and negative charges. Kalidium foliatum biochar $\left(\mathrm{B}_{\mathrm{KF}}\right)$ possessed more negative charges, while Suaeda altissima biochar $\left(\mathrm{B}_{\mathrm{SA}}\right)$ contained more positive charges. In general, the halophyte biochars had a higher ash content and lower point of zero net charge (PZNC) value, compared with the biochars derived from glycophytes, which would imply their higher potential value as an acidic soil conditioner.
\end{abstract}

\section{Highlights}

1. The biochar derived from Suaeda salsa had high ash and sodium salt.

2. The biochar derived from Phragmites australis had the largest specific surface area.

3. The biochar derived from Kalidium foliatum carried much higher negative charge.

Keywords Halophyte $\cdot$ Biochar $\cdot$ Structural elements $\cdot$ Mineral elements $\cdot$ Surface charges

\section{Introduction}

Halophytes including three categories of euhalophytes, recretohalophytes, and pseudohalophytes are a group of plants that can complete their life cycle under highly saline conditions such as salt-affected soils. There are approximately 1560 species of hylophytes in the world and more than 500

Qimei Lin

linqm@cau.edu.cn

1 Department of Soil and Water Science, College of Land Science and Technology, China Agricultural University, Beijing 100193, China

2 Agricultural and Animal Husbandry Technology Extension and Service Center of Wuyuan County, Bayannur 015100, Inner Mongolia, China species in China (Zhao et al. 2002). Most of the salt-affected soils, about $9.55 \times 10^{8}$ ha in the world and $9.91 \times 10^{7}$ ha in China, can well grow certain halophytes (Qadir et al. 2000; Zhao et al. 2002). There is therefore a huge volume of halophyte biomass produced in the salt-affected regions. Unfortunately, most of the halophyte biomass is not properly utilized though a tiny amount as animal forage (Ventura et al. 2015). It is thus meaningful to develop an innovative approach to properly use halophyte biomass.

Pyrolysis, among the ways to use halophyte biomass, has received particularly much attention in recent years. The products of both bio-oil and biogas can be directly used as fuel and industrial starting materials as well (Yue et al. 2016). The most interesting product, namely biochar, has a myriad of functions and can be used in industry, environment, and agriculture (Sohi et al. 2010). It is widely believed 
that the most attractive application of biochar may be as a soil conditioner (Kavitha et al. 2018). A remarkable volume of data have shown that biochar amendments can significantly improve soil physical, chemical, and even microbiological fertilities (Lehmann et al. 2011; Luo et al. 2012; Guo et al. 2019; Amoah-Antwi et al. 2020). Cereal productivity and root biomass are thereafter significantly enhanced due to biochar amendment (Hussain et al. 2017). Moreover, biochar amendment can play a pivotal role in enlarging soil carbon sequestration capacity and reducing greenhouse gas emissions as well (Liu et al. 2018). It is well documented that the properties of biochar directly determine its application and the effects. For example, wood-based biochar is suitable to be considered as a solid fuel and adsorbent (Zhang et al. 2017), while both fibrous and manure biochars may engender high impacts on soil quality (Shi et al. 2019; Han et al. 2017). It is, therefore, necessary to analyze and evaluate the properties of biochar before amending into soil.

It is well known that the characteristics of biochar depend on both feedstock and pyrolysis process (Chen et al. 2019). However, there is little knowledge of the biochars derived from different halophytes. Halophytes are diverse in botany, anatomy, and salt tolerance. Euhalophytes can absorb a large amount of salt from the environment and accumulate it in succulent tissue. The salt content is measured up to $43 \%$ of dry matter (Zhao et al. 2013a, b). The specific tissues like salt glands, salt bladders may influence the pore development during pyrolysis (Flowers et al. 2015). The specific nature of halophytes may affect not only the pyrolysis process but the biochar characteristics and applications as well (Mao et al. 2019).

In this study, five typical halophytes widely distributed in the arid regions of China were harvested and then slowly pyrolyzed in a fixed bed for $1 \mathrm{~h}$. We hypothesized that the biochars derived from the five halophytes might have different characteristics and potential value as a soil conditioner considering their distinct botanic characteristics. The objectives of this study were to understand the specific characteristics of five halophyte biochars, and then evaluate their particular potential value as a soil conditioner, compared with those from glycophytes.

\section{Materials and methods}

\subsection{Feedstock}

The selected five typical halophytes were three euhalophytes of Suaeda altissima (Linn.) Pall. (SA), Suaeda salsa (Linn.) Pall. (SS), and Kalidium foliatum (Pall.) Moq. (KF), one recretohalophyte of Phragmites australis (PA) and one pseudohalophyte of Tamarix chinensis Lour. (TC). The basic properties of the five halophytes are shown in Table 1.

\subsection{Preparation of biochar}

One hundred grams of halophyte dry matter $(<1 \mathrm{~cm})$ was tightly compacted into a pyrolysis reactor with screw lids at both ends in which one was connected to a steel tube for $\mathrm{N}_{2}$ gas flow. The reactors were placed in a muffle furnace (SX4-10, Shuli, China), heated to $500{ }^{\circ} \mathrm{C}$ at a rate of approximately $10^{\circ} \mathrm{C} \mathrm{min}^{-1}$, and then maintained for $1 \mathrm{~h}$. The whole pyrolysis process was performed under pure $\mathrm{N}_{2}$ gas atmosphere (10psi). After cooling to room temperature, the biochars were collected and weighed to calculate the biochar yield. The biochar derived from the Suaeda altissima (Linn.) Pall., Suaeda salsa (Linn.) Pall., Kalidium foliatum (Pall.) Moq., Phragmites australis, and Tamarix chinensis Lour. were defined as $\mathrm{B}_{\mathrm{SA}}, \mathrm{B}_{\mathrm{SS}}, \mathrm{B}_{\mathrm{KF}}, \mathrm{B}_{\mathrm{PA}}$, and $\mathrm{B}_{\mathrm{TC}}$, respectively.

\subsection{Analysis of biomass and biochar}

The cellulose, hemicellulose, and lignin contents in the feedstocks were determined by the Van Soest method (Van Soest et al. 1991). The ash content was determined by heating at $550{ }^{\circ} \mathrm{C}$ for $4 \mathrm{~h}$ in a muffle furnace (Yue et al. 2017). The contents of carbon $(\mathrm{C})$, hydrogen $(\mathrm{H})$, and nitrogen $(\mathrm{N})$ were measured with an elemental analyzer (Elementar

Table 1 The chemical properties of the five halophyte feedstocks

\begin{tabular}{lllllllllllll}
\hline Feedstocks & Ash & $\mathrm{C}$ & $\mathrm{H}$ & $\mathrm{N}$ & $\mathrm{O}$ & $\mathrm{H} / \mathrm{C}_{\mathrm{a}}$ & $\mathrm{O} / \mathrm{C}_{\mathrm{a}}$ & $\mathrm{C} / \mathrm{N}_{\mathrm{m}}$ & $(\mathrm{O}+\mathrm{N}) / \mathrm{C}_{\mathrm{a}}$ & $\begin{array}{l}\text { Hemicellulose } \\
\%\end{array}$ & Cellulose & Lignin \\
& $\%$ & & & & & & & & & & & \\
\hline Suaeda altissima (SA) & $5.92 \mathrm{c}$ & $44.19 \mathrm{~b}$ & $6.60 \mathrm{a}$ & $0.589 \mathrm{~cd}$ & $42.26 \mathrm{a}$ & $1.79 \mathrm{~b}$ & $0.717 \mathrm{a}$ & $87.47 \mathrm{ab}$ & $0.728 \mathrm{a}$ & $25.84 \mathrm{~d}$ & $44.97 \mathrm{a}$ & $9.47 \mathrm{c}$ \\
Suaeda salsa (SS) & $7.71 \mathrm{a}$ & $41.06 \mathrm{~d}$ & $6.20 \mathrm{c}$ & $0.518 \mathrm{~d}$ & $36.62 \mathrm{c}$ & $1.81 \mathrm{a}$ & $0.669 \mathrm{~b}$ & $92.45 \mathrm{a}$ & $0.680 \mathrm{~b}$ & $28.07 \mathrm{c}$ & $36.46 \mathrm{~b}$ & $7.34 \mathrm{~d}$ \\
Kalidium foliatum (KF) & $6.40 \mathrm{~b}$ & $43.30 \mathrm{c}$ & $6.53 \mathrm{~b}$ & $1.24 \mathrm{a}$ & $38.76 \mathrm{~b}$ & $1.81 \mathrm{a}$ & $0.671 \mathrm{~b}$ & $40.75 \mathrm{~d}$ & $0.696 \mathrm{~b}$ & $30.06 \mathrm{~b}$ & $32.16 \mathrm{c}$ & $10.48 \mathrm{~b}$ \\
Phragmites australis (PA) & $8.18 \mathrm{a}$ & $43.16 \mathrm{c}$ & $6.32 \mathrm{c}$ & $0.772 \mathrm{~b}$ & $38.79 \mathrm{~b}$ & $1.76 \mathrm{c}$ & $0.674 \mathrm{~b}$ & $65.39 \mathrm{c}$ & $0.689 \mathrm{~b}$ & $31.04 \mathrm{a}$ & $36.88 \mathrm{~b}$ & $7.32 \mathrm{~d}$ \\
Tamarix chinensis (TC) & $2.50 \mathrm{c}$ & $45.94 \mathrm{a}$ & $6.53 \mathrm{~b}$ & $0.650 \mathrm{c}$ & $34.58 \mathrm{~d}$ & $1.71 \mathrm{~d}$ & $0.564 \mathrm{c}$ & $82.55 \mathrm{~b}$ & $0.576 \mathrm{c}$ & $22.06 \mathrm{e}$ & $36.96 \mathrm{~b}$ & $12.44 \mathrm{a}$ \\
Means & 6.14 & 43.53 & 6.44 & 0.755 & 38.20 & 1.78 & 0.659 & 73.72 & 0.674 & 27.41 & 37.49 & 9.41 \\
\hline
\end{tabular}

The $\mathrm{H} / \mathrm{C}_{\mathrm{a}}, \mathrm{O} / \mathrm{C}_{\mathrm{a}}$ and $(\mathrm{O}+\mathrm{N}) / \mathrm{C}_{\mathrm{a}}$ are the ratios among the atomic numbers of $\mathrm{H}, \mathrm{O}, \mathrm{N}$ and $\mathrm{C}$. The $\mathrm{C} / \mathrm{N}_{\mathrm{m}}$ is the mass ratio between $\mathrm{C}$ and $\mathrm{N}$. The different lower-case letters in the same line represent the significant difference at $p<0.05$ among the different feedstocks 
Analysensysteme GmbH, Hanau, Germany), while oxygen (O) content was calculated by the subtraction method [O\% $\left.=100 \%-\left(\mathrm{H}_{2} \mathrm{O} \%+\mathrm{Ash} \%+\mathrm{C} \%+\mathrm{H} \%+\mathrm{N} \%\right)\right]($ Chen et al. 2019). Following extraction with distilled water at the ratio of $1: 10(\mathrm{w} / \mathrm{v})$, the $\mathrm{pH}$ value of the extracts was determined using a UB-7 pH meter while EC was measured with a DDS-307A conductivity meter and dissolved organic carbon (DOC) was measured by TOC instrumentation (Elementar varioTOC, Germany). After digestion with sulfuric acid $\left(\mathrm{H}_{2} \mathrm{SO}_{4}\right)$-hydrogen peroxide $\left(\mathrm{H}_{2} \mathrm{O}_{2}\right)$, the dissolved organic nitrogen (DON) of the extracts was determined by the Kjeldahl method, the dissolved organic phosphorus (DOP) by molybdenum antimony resistance colorimetry, potassium $(\mathrm{K})$, calcium $(\mathrm{Ca})$, sodium $(\mathrm{Na})$, and magnesium $(\mathrm{Mg})$ by inductively coupled plasma optical emission spectrometry (ICP-OES, Avio 200, Perkin-Elmer, USA).

The morphological characteristics of the biochars were observed with a scanning electron microscope (S-3400N, HITACHI, Japan). The pore structure was determined with a specific surface area analyzer (BK122T B, JWGB, China) according to the nitrogen adsorption-static volumetric method. The mesopores and macropores were calculated according to the method suggested by Barrett, Joyner and Halenda, while the micropores by the method of Saito and Foley (Zhao et al. 2014). The surface charge was measured by the ion adsorption exchange method (Cheng et al. 2008). The point of zero charge (PZNC) value was the $\mathrm{pH}$ value when the positive and negative charges were equal. The anion exchange capacity (AEC) was the amount of positive surface charge at $\mathrm{pH} 3.5$. The cation exchange capacity (CEC) was the amount of negative surface charge at $\mathrm{pH} 7.0$ (Cheng et al. 2008).

\subsection{Statistical analysis}

The differences in pyrolysis products prepared under different temperatures were compared through one-way analysis of variance and then expressed as the least significant difference (LSD). A $p$-value $<0.05$ was considered statistically significant.

\section{Results and discussion}

\subsection{Yield}

The five typical halophyte feedstocks had a similar biochar yield, ranging from 32.75 to $39.20 \%$, under the slow pyrolysis process at $500{ }^{\circ} \mathrm{C}$ for $1 \mathrm{~h}$ (Table 2). The biochar yields of the halophyte feedstocks were close to those of the fibrous materials such as gramineous crop straws, while much lower than those of woody, animal manure, and sludge feedstocks (Hassan et al. 2020; Hopkins and Hawboldt, 2020). It is known that the large molecules in the feedstocks are broken and converted into small molecules during pyrolysis (Chen and Chen 2009). The yield of biochar is therefore dependent on the characteristics of the feedstock and the pyrolysis process. In a specific pyrolysis process, especially at a certain pyrolysis temperature, the yield of biochar is mainly decided by the characteristics of the feedstock. Zhao et al. $(2013 a, b)$ reported that the feedstocks with high ash and lignin contents often had a high yield in biochar. However, a weak relationship between the ash content in the feedstocks and biochar yield was found in this study $(r=0.55$, $p>0.05)$. The carbon content of the halophytes was closely related to the biochar yield $(\mathrm{r}=0.83, p<0.05)$, which might imply that lignin content in the halophytes rather than the ash determined the biochar production.

\subsection{Structural elements}

The obtained biochars from the five typical halophytes had similar contents of structural elements, compared to those of glycophyte-derived biochars (Sun et al. 2013). They had higher $\mathrm{C}$ and $\mathrm{N}$ contents, $58.50-71.73 \%$ and $0.66-1.49 \%$ respectively, compared to the feedstocks (Table 2), which showed the relative enrichment of both $\mathrm{C}$ and $\mathrm{N}$ during
Table 2 The basic chemical properties of the biochars derived from five halophytes under $500^{\circ} \mathrm{C}$ for $1 \mathrm{~h}$

\begin{tabular}{lllllllllll}
\hline Biochar & $\begin{array}{l}\text { Yield } \\
\%\end{array}$ & $\mathrm{C}$ & $\mathrm{H}$ & $\mathrm{N}$ & $\mathrm{O}$ & $\mathrm{Ash}$ & $\mathrm{H} / \mathrm{C}_{\mathrm{a}}$ & $\mathrm{O} / \mathrm{C}_{\mathrm{a}}$ & $\mathrm{C} / \mathrm{N}_{\mathrm{m}}$ & $(\mathrm{O}+\mathrm{N}) / \mathrm{C}_{\mathrm{a}}$ \\
\hline $\mathrm{B}_{\mathrm{SA}}$ & $32.75 \mathrm{~b}$ & $71.34 \mathrm{~b}$ & $4.25 \mathrm{a}$ & $0.664 \mathrm{~d}$ & $6.03 \mathrm{~d}$ & $12.81 \mathrm{c}$ & $0.715 \mathrm{a}$ & $0.0634 \mathrm{c}$ & $125.56 \mathrm{a}$ & $0.0714 \mathrm{c}$ \\
$\mathrm{B}_{\mathrm{SS}}$ & $39.20 \mathrm{a}$ & $58.50 \mathrm{e}$ & $3.40 \mathrm{c}$ & $0.915 \mathrm{c}$ & $8.92 \mathrm{~b}$ & $23.64 \mathrm{a}$ & $0.697 \mathrm{~b}$ & $0.114 \mathrm{a}$ & $74.59 \mathrm{bc}$ & $0.128 \mathrm{a}$ \\
$\mathrm{B}_{\mathrm{KF}}$ & $34.07 \mathrm{~b}$ & $65.08 \mathrm{c}$ & $3.40 \mathrm{c}$ & $1.49 \mathrm{a}$ & $6.78 \mathrm{~cd}$ & $18.84 \mathrm{~b}$ & $0.626 \mathrm{c}$ & $0.0781 \mathrm{~b}$ & $51.10 \mathrm{~d}$ & $0.0977 \mathrm{~b}$ \\
$\mathrm{~B}_{\mathrm{PA}}$ & $33.37 \mathrm{~b}$ & $61.21 \mathrm{~d}$ & $2.90 \mathrm{~d}$ & $1.03 \mathrm{~b}$ & $7.66 \mathrm{bc}$ & $23.13 \mathrm{a}$ & $0.569 \mathrm{~d}$ & $0.0938 \mathrm{~b}$ & $69.61 \mathrm{c}$ & $0.108 \mathrm{~b}$ \\
$\mathrm{~B}_{\mathrm{TC}}$ & $33.05 \mathrm{~b}$ & $71.73 \mathrm{a}$ & $3.76 \mathrm{~b}$ & $1.03 \mathrm{~b}$ & $11.81 \mathrm{a}$ & $7.26 \mathrm{~d}$ & $0.629 \mathrm{c}$ & $0.123 \mathrm{a}$ & $81.32 \mathrm{~b}$ & $0.136 \mathrm{a}$ \\
Means & 34.49 & 65.57 & 3.54 & 1.03 & 8.24 & 17.14 & 0.647 & 0.0946 & 80.44 & 0.108 \\
\hline
\end{tabular}

The $\mathrm{H} / \mathrm{C}_{\mathrm{a}}, \mathrm{O} / \mathrm{C}_{\mathrm{a}}$ and $(\mathrm{O}+\mathrm{N}) / \mathrm{C}_{\mathrm{a}}$ are the ratios among the atomic numbers of $\mathrm{H}, \mathrm{O}, \mathrm{N}$ and $\mathrm{C}$. The $\mathrm{C} / \mathrm{N}_{\mathrm{m}}$ is the mass ratio between $\mathrm{C}$ and $\mathrm{N}$. The different lower-case letters in the same line represent the significant difference at $p<0.05$ among the different biochars 
pyrolysis. The significant positive correlation between the $\mathrm{C}$ and $\mathrm{N}$ in the feedstocks and their biochars $(\mathrm{r}=0.90$, $p<0.01)$ might imply that enrichments of both $\mathrm{C}$ and $\mathrm{N}$ in the biochars were proportional to those in the feedstocks. In contrast, both $\mathrm{O}$ and $\mathrm{H}$ contents in the biochars decreased from $34.58-42.26 \%$ to $6.03-11.81 \%$ and $6.20-6.60 \%$ to $2.90-4.25 \%$, respectively, which indicated remarkable losses of both $\mathrm{O}$ and $\mathrm{H}$ during pyrolysis. The chemical reactions such as dehydration, dehydrogenation, deoxygenation, and decarboxylation occuring during pyrolysis can cause large changes in these structural elements, in which $\mathrm{C}$ is relatively enriched, while $\mathrm{O}$ reduced, with small changes in both $\mathrm{H}$ and $\mathrm{N}$ (Yue et al. 2017). In addition, the significant relationships of $\mathrm{C}$ vs lignin $(\mathrm{r}=0.82, p<0.01)$ and hemicellulose $(\mathrm{r}=-0.75, p<0.01), \mathrm{O}$ and $\mathrm{H}$ vs hemicellulose $(\mathrm{r}=-0.71,-0.65$, respectively; $p<0.05), \mathrm{H}$ vs cellulose $(\mathrm{r}=0.70, p<0.01)$, and $\mathrm{N}$ vs cellulose $(\mathrm{r}=-0.92, p<0.01)$ might reveal the complicated reactions and changes during pyrolysis.

The atomic ratios of $\mathrm{H} / \mathrm{C}_{\mathrm{a}}, \mathrm{O} / \mathrm{C}_{\mathrm{a}}$ and $(\mathrm{O}+\mathrm{N}) / \mathrm{C}_{\mathrm{a}}$ in the biochars decreased by $63 \%, 86 \%$, and $84 \%$, respectively, while the mass ratio of $\mathrm{C} / \mathrm{N}_{\mathrm{m}}$ increased by $9 \%$, compared with those of the feedstocks. The values of $\mathrm{H} / \mathrm{C}_{\mathrm{a}}$ and $\mathrm{C} /$ $\mathrm{N}_{\mathrm{m}}$ in the biochars were independent of those of feedstocks, while both $\mathrm{O} / \mathrm{C}_{\mathrm{a}}$ and $(\mathrm{O}+\mathrm{N}) / \mathrm{C}_{\mathrm{a}}$ ratios in the feedstocks negatively decided those in the biochars $(\mathrm{r}=-0.83,-0.84$, respectively, $p<0.01$ ). It was evident that $\mathrm{O}$ in the feedstocks might undergo deoxygenation and decarboxylation and thus result in a high loss of $\mathrm{O}$ (Calvelo Pereira et al. 2011). The means of $H / C_{a}, O / C_{a}$ and $(O+N) / C_{a}$ and $C / N_{m}$ in the halophyte-derived biochars were $0.65,0.09,0.11$, and 80.44 , respectively, which fell within the ranges of those from glycophytes (Wang et al. 2015). However, the low ratios of $\mathrm{H} / \mathrm{C}_{\mathrm{a}}, \mathrm{O} / \mathrm{C}_{\mathrm{a}}$ and $\mathrm{C} / \mathrm{N}_{\mathrm{m}}$ of both $\mathrm{B}_{\mathrm{KF}}$ and $\mathrm{B}_{\mathrm{PA}}$ might indicate a high degree of aromatization and therefore a stable structure (Yan et al. 2012).

\subsection{Mineral elements}

It is widely known that biochar usually contains a certain amount of ash, showing alkalinity and high EC value since the feedstock contains a certain number of mineral elements. Those minerals can be mostly remained in the biochar during the pyrolysis process (Shi et al. 2019). The halophytederived biochars in this study had variable contents in ash, $\mathrm{EC}$, and $\mathrm{pH}$ values, ranging from $7.26-23.64 \%, 1.76-23.45$ $\mathrm{mS} \mathrm{cm}{ }^{-1}$ and PH 7.86-10.47, respectively. The ash content of the biochars was linearly related to that in the halophyte feedstocks $(\mathrm{r}=0.97, p<0.01)$. The biochars derived from euhalophytes, such as $\mathrm{B}_{\mathrm{SA}}$ and $\mathrm{B}_{\mathrm{SS}}$, had much higher ash since they developed a compartmentalized vacuole structure for salt storage (Table 2). The glycophyte-derived biochar was reported to have ash content ranging from 2.28 to $37.3 \%$ (Zhang et al. 2017; Han et al. 2017), while that of biochars from manure and sludge was relatively high, $14.41-57.45 \%$ (Singh et al. 2010; Xiao et al. 2019). Generally, the ash content of the halophyte-derived biochars was higher than that of most glycophyte-derived biochars, but lower than that of manure and sludge biochars.

The halophyte-derived biochars had a diverse composition of minerals, dominated in $\mathrm{Na}\left(1.06-33.93 \mathrm{~g} \mathrm{~kg}^{-1}\right)$, followed by $\mathrm{K}$ (1.68-6.17 $\mathrm{g} \mathrm{kg}^{-1}$ ) (Table 3). The euhalophytederived biochars such as $\mathrm{B}_{\mathrm{SA}}, \mathrm{B}_{\mathrm{SS}}, \mathrm{B}_{\mathrm{KF}}$ had relatively high contents of both $\mathrm{Na}$ and $\mathrm{Mg}$, while the recretohalophyte biochar of $\mathrm{B}_{\mathrm{PA}}$ was high in $\mathrm{K}$, and pseudohalophyte biochar of $\mathrm{B}_{\mathrm{TC}}$ high in $\mathrm{Ca}$. It was obvious that halophyte-derived biochars had a comparable Na content with manure biochar (Subedi et al. 2015), but much higher than glycophytederived biochar (0.17-2.00 $\mathrm{mg} \mathrm{kg}^{-1}$ ) (Suliman et al. 2015).

The minerals as the main portion of the ash in biochar often exist as oxides, hydroxides, carbonates, phosphates and what like, which are assumed to be related to the $\mathrm{pH}$ and EC values in biochar (Hung et al. 2017; Piash et al. 2021). The ash percentage of the halophyte biochars was strongly related to the $\mathrm{pH}$ value $(\mathrm{r}=0.84, p<0.05)$ and $\mathrm{K}$ content $(\mathrm{r}=0.94, p<0.01)$, but weakly to $\mathrm{EC}$ value $(\mathrm{r}=0.61, p>0.05)$. The EC value was strongly dependent on $\mathrm{Na}$ content in the biochars $(\mathrm{r}=0.99, p<0.01)$, while the $\mathrm{pH}$ value was somewhat linked with $\mathrm{K}$ content $(\mathrm{r}=0.69, \mathrm{n}=4)$ rather than $\mathrm{Na}$ content $(\mathrm{r}=0.42, \mathrm{n}=4)$ in the biochars. Cantrell et al. (2011) measured that less than one-third of the ash could be dissolved in water,

Table 3 The $\mathrm{pH}, \mathrm{EC}$ value and dissolved element content of the biochars derived from five halophytes under $500{ }^{\circ} \mathrm{C}$ for $1 \mathrm{~h}$

\begin{tabular}{|c|c|c|c|c|c|c|c|c|c|}
\hline Biochar & $\mathrm{pH}$ & $\begin{array}{l}\mathrm{EC} \\
\left(\mathrm{mS} \mathrm{cm}^{-1}\right)\end{array}$ & $\begin{array}{l}\mathrm{Na}^{+} \\
\mathrm{g} \mathrm{kg}^{-1}\end{array}$ & $\mathrm{~K}^{+}$ & $\mathrm{Ca}^{2+}$ & $\mathrm{Mg}^{2+}$ & $\begin{array}{l}\text { DOC } \\
\mathrm{mg} \mathrm{kg}^{-1}\end{array}$ & DON & DOP \\
\hline $\mathrm{B}_{\mathrm{SA}}$ & $9.35 \pm 0.50 \mathrm{c}$ & $2.64 \pm 0.78 c$ & $5.48 \pm 0.12 c$ & $1.97 \pm 0.01 \mathrm{~d}$ & $0.0146 \pm 0.01 \mathrm{~d}$ & $0.981 \pm 0.02 \mathrm{c}$ & $3586.25 \pm 0.24 a$ & $123.69 \pm 0.02 \mathrm{a}$ & $14.20 \pm 0.10 \mathrm{~d}$ \\
\hline $\mathrm{B}_{\mathrm{SS}}$ & $9.77 \pm 0.06 b c$ & $23.45 \pm 4.61 \mathrm{a}$ & $33.93 \pm 0.56 a$ & $6.17 \pm 0.02 b$ & $0.0303 \pm 0.01 \mathrm{c}$ & $1.20 \pm 0.17 b$ & $3256.00 \pm 0.15 \mathrm{a}$ & $86.88 \pm 0.02 \mathrm{ab}$ & $94.04 \pm 6.71 \mathrm{a}$ \\
\hline $\mathrm{B}_{\mathrm{KF}}$ & $10.47 \pm 0.17 \mathrm{a}$ & $8.10 \pm 1.15 b$ & $14.64 \pm 0.09 b$ & $5.07 \pm 0.07 \mathrm{c}$ & $0.0237 \pm 0.01 \mathrm{~cd}$ & $1.62 \pm 0.07 \mathrm{a}$ & $3283.63 \pm 0.01 \mathrm{a}$ & $104.19 \pm 0.00 \mathrm{a}$ & $2.40 \pm 0.00 \mathrm{e}$ \\
\hline $\mathrm{B}_{\mathrm{PA}}$ & $10.07 \pm 0.11 \mathrm{ab}$ & $2.91 \pm 0.56 \mathrm{c}$ & $3.72 \pm 0.24 \mathrm{~d}$ & $9.44 \pm 0.08 \mathrm{a}$ & $0.0945 \pm 0.00 \mathrm{~b}$ & $0.323 \pm 0.01 \mathrm{~d}$ & $886.69 \pm 0.33 b$ & $58.94 \pm 0.02 b$ & $41.19 \pm 2.01 \mathrm{c}$ \\
\hline $\mathrm{B}_{\mathrm{TC}}$ & $7.86 \pm 0.12 \mathrm{~d}$ & $1.76 \pm 0.25 \mathrm{c}$ & $1.06 \pm 0.00 \mathrm{e}$ & $1.68 \pm 0.04 \mathrm{e}$ & $1.60 \pm 0.03 \mathrm{a}$ & $0.880 \pm 0.05 \mathrm{c}$ & $634.06 \pm 0.02 b$ & $57.94 \pm 0.01 b$ & $89.74 \pm 4.02 b$ \\
\hline Means & 9.5 & 7.77 & 13.82 & 5.08 & 0.416 & 1.00 & 2329.33 & 86.33 & 48.31 \\
\hline
\end{tabular}

The different lower-case letters in the same line represent the significant difference at $p<0.05$ among the different biochars 
which might explain the inconsistency of ash with EC value. Current data have shown that the ash composition in biochar is attributed to its liming effect in acid soils (Masud et al. 2020). Halophyte-derived biochars may therefore have a remarkable liming effect for their high ash content. However, the biochars should be checked for their high $\mathrm{Na}$ content which may cause a risk for some $\mathrm{Na}^{+}$-sensitive plants.

Remarkable amounts of dissolved organic carbon, nitrogen, and phosphorus (DOC, DON, DOP) were detected in the halophyte-derived biochars (Table 3), which fell within the ranges of those in glycophyte biochars (Wu et al. 2012). The biochars derived from euhalophytes, such as $\mathrm{B}_{\mathrm{SA}}, \mathrm{B}_{\mathrm{SS}}$, and $\mathrm{B}_{\mathrm{KF}}$, had higher dissolved organic carbon than the biochar from either recretohalophyte $\left(\mathrm{B}_{\mathrm{PA}}\right)$ or pseudohalophyte $\left(\mathrm{B}_{\mathrm{TC}}\right)$. The $\mathrm{B}_{\mathrm{SS}}$ even had high DOP, $94.04 \mathrm{mg} \mathrm{kg}^{-1}$. It was not certain whether more dissolved organic matter might be released during the pyrolysis process of euhalophyte. It is believed that the dissolved organic matter in biochar can be used as a substrate for microorganisms and thus influence the microbial activity and community structure as well (Luo et al. 2012). Some of the small molecules in biochar were reported to stimulate or inhibit plant growth (Yuan et al. 2021). It would be worthy of understanding the unique composition of the dissolved organic matter in halophytederived biochar and its impacts on soil microbes.

\subsection{Pore structure}

Biochar usually has a porous structure since the organic matter in the feedstock is gradually volatilized during the pyrolysis process. The porosity of biochar is therefore dependent on both feedstock and pyrolysis conditions such as temperature. However, the anatomical structure of the feedstock may largely decide the biochar porosity under-designed pyrolysis conditions (Lehmann et al. 2011). The obtained biochars in this study had distinct pore structures depending on the halophyte feedstocks (Fig. 1). Both $\mathrm{B}_{\mathrm{SA}}$ and $\mathrm{B}_{\mathrm{SS}}$ possessed mainly mesopores of $2-50 \mathrm{~nm}$, and thus had higher values of porosity, mode pore diameter (MPD), and average pore size (APS). The biochars of $\mathrm{B}_{\mathrm{KF}}, \mathrm{B}_{\mathrm{PA}}$, and $\mathrm{B}_{\mathrm{TC}}$ were dominant in $1-3 \mathrm{~nm}$ pores, and had low values of MPD and APS, while both the specific surface area (SSA) and pore volume were relatively large. Among the five biochars, $\mathrm{B}_{\mathrm{PA}}$ had the largest SSA and pore volume (PV), $344.02 \mathrm{~m}^{2} \mathrm{~g}^{-1}$, and 0.24 $\mathrm{cm}^{3} \mathrm{~g}^{-1}$, respectively (Table 3). Both feedstocks of Suaeda altissima and Suaeda salsa had an anatomical structure of salt compartmentalization, and might easily form columnar and cavity-like large pores. The feedstocks of Phragmites australis and Tamarix chinensis Lour. could readily develop fine and small pores for their uniform and dense anatomical structure (Figs. 2, 3). In particular, the biomass of Phragmites australis might be likely to form more pores for its well-developed vascular structure (Fig. 2).

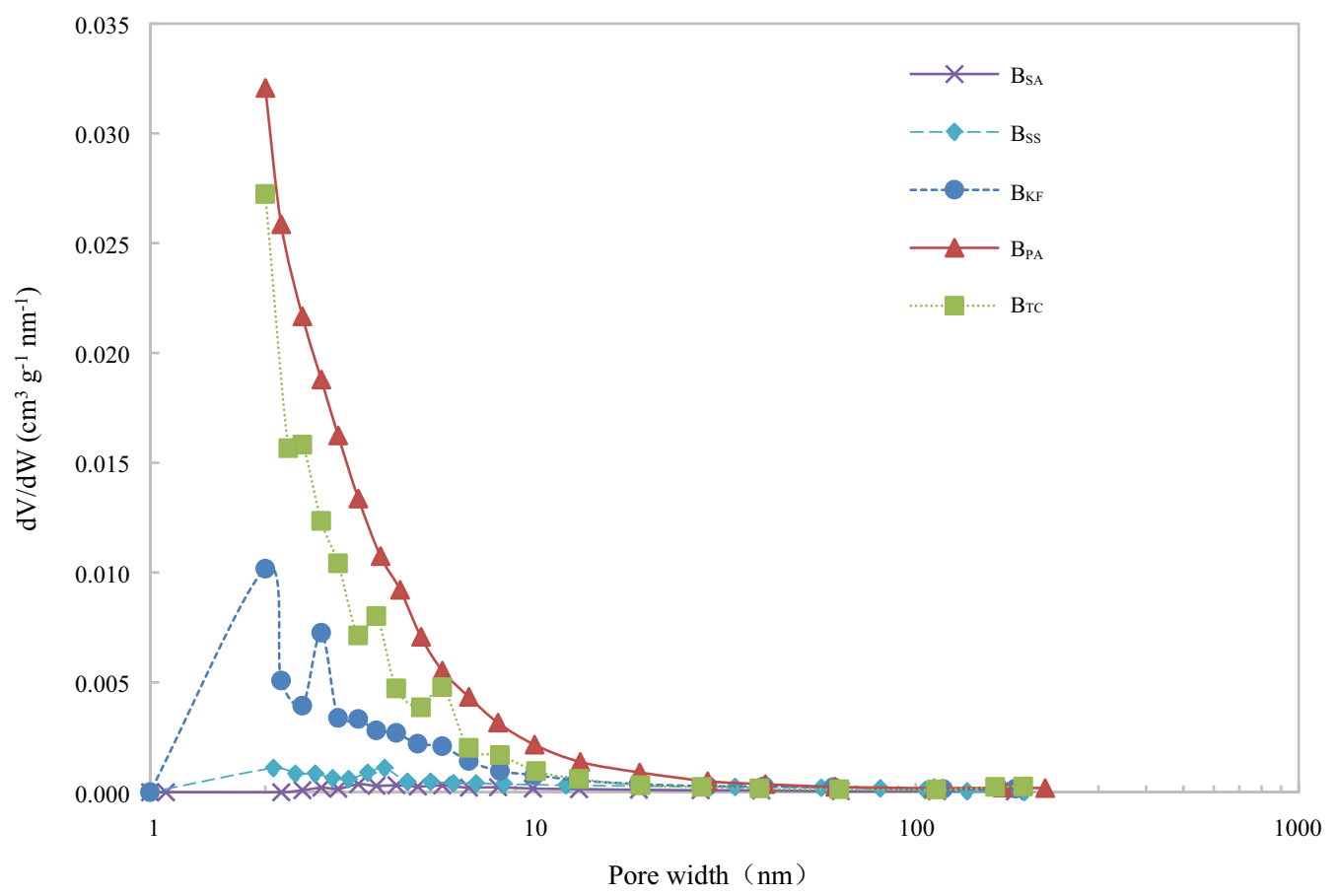

Fig. 1 Distribution of pore volume in the biochars derived from five halophytes ( $B_{S A}$ Suaeda altissima biochar; $B_{S S}$ Suaeda salsa biochar; $B_{K F}$ Kalidium foliatum biochar; $B_{P A}$ Phragmites australis biochar; $B_{T C}$ Tamarix chinensis biochar) 


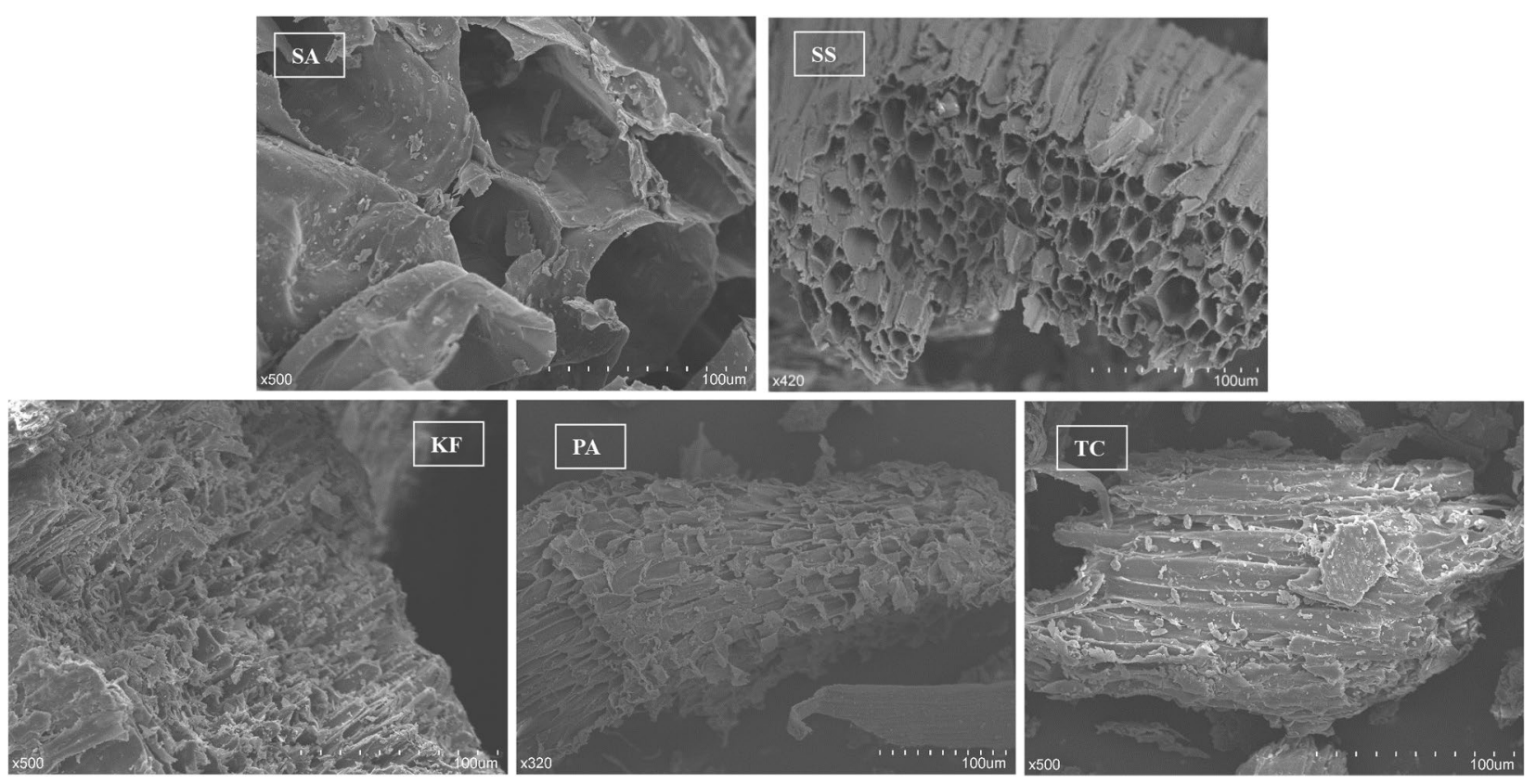

Fig. 2 SEM imagines of the five halophyte feedstocks (SA Suaeda altissima; SS Suaeda salsa; KF Kalidium foliatum; PA Phragmites australis; TC Tamarix chinensis)
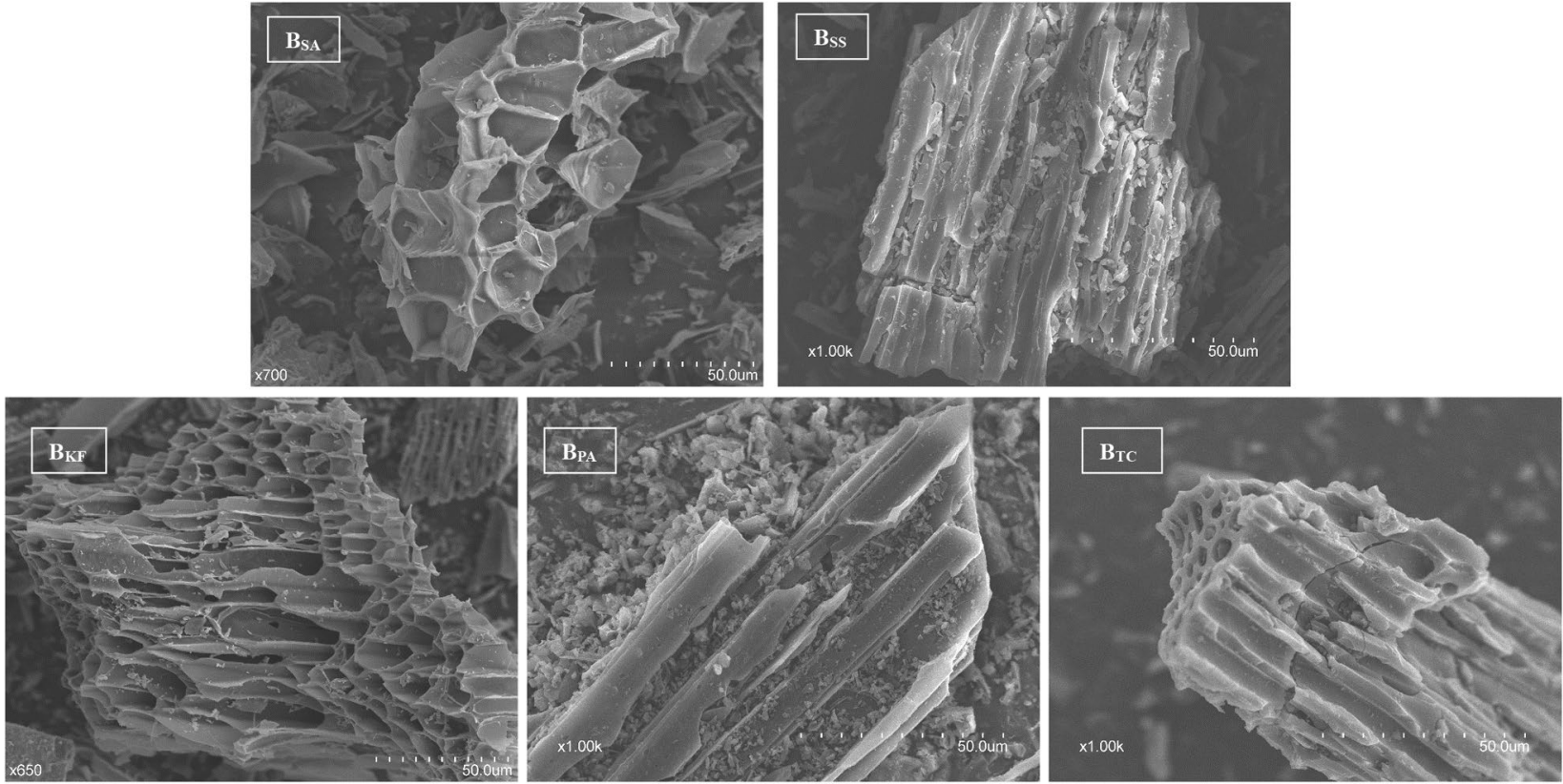

Fig. 3 SEM imagines of the biochars derived from five halophytes ( $B_{S A}$ Suaeda altissima biochar; $B_{S S}$ Suaeda salsa biochar; $B_{K F}$ Kalidium foliatum biochar; $B_{P A}$ Phragmites australis biochar; $B_{T C}$ Tamarix chinensis biochar)

A large number of data has shown that the biochar with a well-developed pore structure and the large SSA often has strong adsorption capacity for ions, polar and nonpolar substances as well (Yue et al. 2016). It can be thereafter used as the absorbent for removing heavy metals such as $\mathrm{Pb}^{2+}, \mathrm{Cd}^{2+}$, and $\mathrm{Cu}^{2+}$ ions (Kalinke et al. 2019). A few studies have reported that biochar amendments can significantly enhance soil water holding capacity (Liu et al. 2015) and nutrient ion retention capacity as well (Rajkovich et al. 2012). In addition, the micropores in biochar can provide habitats for 
bacteria $(0.3-3 \mu \mathrm{m})$ and even fungi $(2.0-80 \mu \mathrm{m})$ and thus help them escape from predators (Luo et al. 2012). Further work may be required for exploring adsorption behaviors of the halophyte-derived biochars with unique pore structures in soil and water as well.

\subsection{Surface charge}

The obtained biochars were all rich in $\mathrm{pH}$-dependent charges (Fig. 4). The positive charge gradually decreased with enhancing medium $\mathrm{pH}$ value. The positive charge of $\mathrm{B}_{\mathrm{SA}}$ decreased from 260.92 to $133.78 \mathrm{cmol} \mathrm{kg}^{-1}$ when the $\mathrm{pH}$ value increased from 1 to 12 (Fig. $4 \mathrm{a}$ ). The positive charge in $\mathrm{B}_{\mathrm{PA}}$ also increased to $149.780 \mathrm{cmol} \mathrm{kg}^{-1}$ though it was the lowest among the tested biochars (Fig. 4c). The negative charge, in contrast, increased with lifting $\mathrm{pH}$ value of the medium. The $\mathrm{B}_{\mathrm{SS}}$ showed higher negative charge, $0.46-172.92 \mathrm{cmol} \mathrm{kg}^{-1}$ (Fig. 4b), while $\mathrm{B}_{\mathrm{PA}}$ lower, $0.52-17.55 \mathrm{cmol} \mathrm{kg}^{-1}$. Our results fell within the reported ranges of the surface charge (Yue et al. 2017; Chen et al. 2019).

The five halophyte-derived biochars had similar values of point of zero net charge (PZNC), $\mathrm{pH} 4.3-5.6$ (Table 4), which might suggest the similarity in their charged functional groups. The low PZNC of the biochars probably (a)

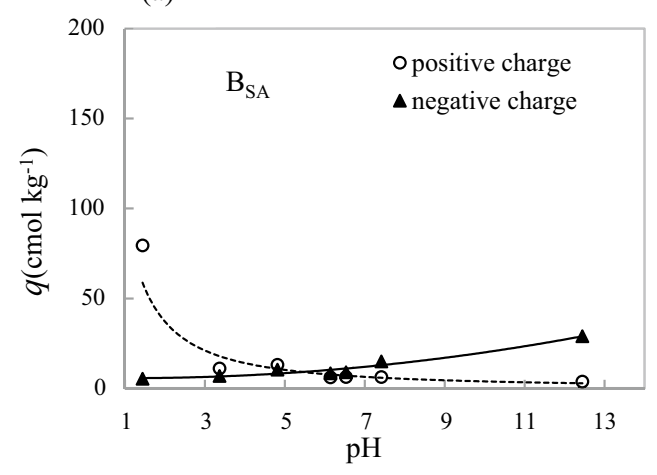

(c)

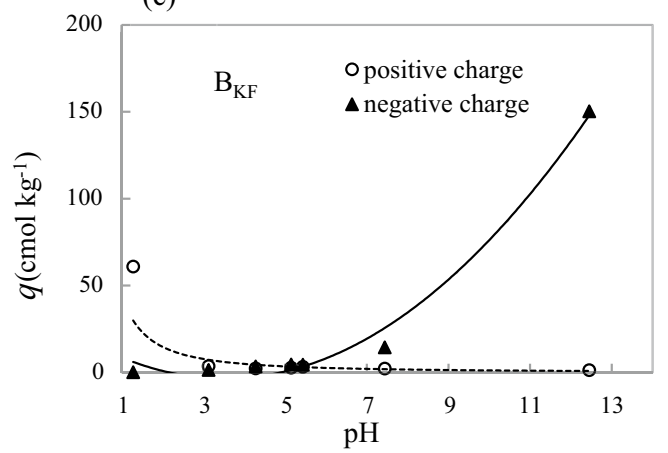

(b)

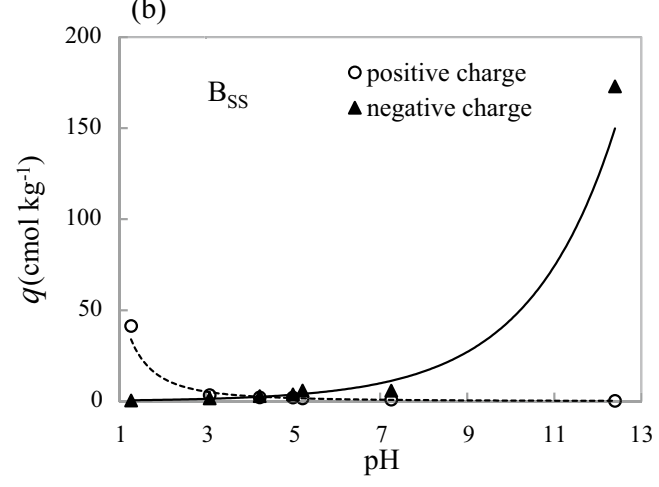

(d)

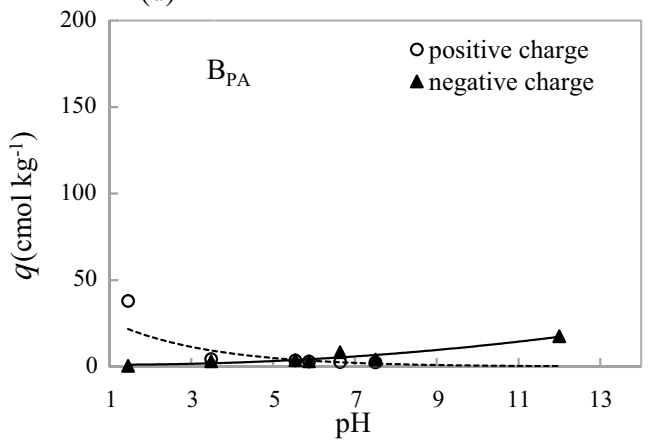

(e)

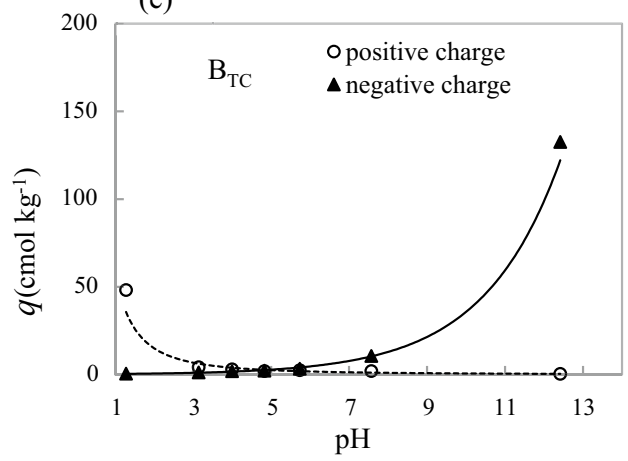

Fig. 4 The surface charges versus pH values for the biochars derived from Suaeda altissima (a); Suaeda salsa (b); Kalidium foliatum (c); Phragmites australis $(\mathbf{d})$ and Tamarix chinensis $(\mathbf{e})$ 
Table 4 Pore structure parameters of the biochars derived from five halophytes under $500{ }^{\circ} \mathrm{C}$ for $1 \mathrm{~h}$

\begin{tabular}{llllll}
\hline Biochar & $\begin{array}{l}\text { SSA } \\
\left(\mathrm{m}^{2} \mathrm{~g}^{-1}\right)\end{array}$ & $\begin{array}{l}\text { PV } \\
\left(\mathrm{cm}^{3} \mathrm{~g}^{-1}\right)\end{array}$ & $\begin{array}{l}\text { APS } \\
(\mathrm{nm})\end{array}$ & $\begin{array}{l}\text { MPD } \\
(\mathrm{nm})\end{array}$ & $\begin{array}{l}\text { MMPS } \\
(\mathrm{nm})\end{array}$ \\
\hline $\mathrm{B}_{\mathrm{SA}}$ & $3.50 \pm 2.36 \mathrm{e}$ & $0.0135 \pm 0.00 \mathrm{e}$ & $19.17 \pm 10.61 \mathrm{a}$ & $18.80 \pm 6.37 \mathrm{~b}$ & $1.26 \pm 0.50 \mathrm{a}$ \\
$\mathrm{B}_{\mathrm{SS}}$ & $9.20 \pm 4.21 \mathrm{~d}$ & $0.0279 \pm 0.00 \mathrm{~d}$ & $12.13 \pm 0.71 \mathrm{~b}$ & $19.25 \pm 8.22 \mathrm{a}$ & $0.941 \pm 0.01 \mathrm{c}$ \\
$\mathrm{B}_{\mathrm{KF}}$ & $46.73 \pm 18.05 \mathrm{c}$ & $0.0670 \pm 0.01 \mathrm{c}$ & $5.11 \pm 0.03 \mathrm{c}$ & $9.67 \pm 4.57 \mathrm{c}$ & $1.16 \pm 0.11 \mathrm{~b}$ \\
$\mathrm{~B}_{\mathrm{PA}}$ & $344.02 \pm 32.10 \mathrm{a}$ & $0.240 \pm 0.11 \mathrm{a}$ & $2.79 \pm 0.01 \mathrm{e}$ & $6.38 \pm 0.07 \mathrm{e}$ & $0.564 \pm 0.02 \mathrm{e}$ \\
$\mathrm{B}_{\mathrm{TC}}$ & $153.64 \pm 69.79 \mathrm{~b}$ & $0.0966 \pm 0.03 \mathrm{~b}$ & $5.76 \pm 2.75 \mathrm{~d}$ & $8.52 \pm 2.05 \mathrm{~d}$ & $0.905 \pm 0.06 \mathrm{~d}$ \\
Means & 111.42 & 0.0891 & 8.99 & 12.53 & 0.967 \\
\hline
\end{tabular}

The different lower-case letters in the same line represent the significant difference at $p<0.05$ among the different biochars

$S S A$ specific surface area; $P V$ pore volume; $A P S$ average pore size; $M P D$ mode pore diameter; $M M P S$ macro-pore median pore size implied a high capacity to enhance negative charge under an alkaline environment.

Compared with other biochars, $\mathrm{B}_{\mathrm{SA}}$ had much higher $\mathrm{AEC}_{\mathrm{pH} 3.5}, 16.99 \mathrm{cmol} \mathrm{kg}^{-1}$, and might be suitable to remove the positively charged pollutants under acidic conditions (Table 5). In contrast, except for $\mathrm{B}_{\mathrm{SA}}$, other four biochars might have better adsorption capacity for negatively charged materials under alkaline conditions since they tended to have a high value of $\mathrm{CEC}_{\mathrm{pH} 7.0} 19.36 \mathrm{cmol} \mathrm{kg}^{-1}$.

It is widely known that biochar usually contains a large number of $\mathrm{pH}$-dependent charges regardless of the feedstock type. The negative charge is assumed to mainly come from functional groups such as hydroxyl and carboxyl groups. The positive charge may be stemmed from nitrogen-containing functional groups, surface oxygen-containing alkaline substances, such as amino, pyrone, or benzopyran, and from the electron-rich centers between graphite layers that attract protons in solution (Chen et al. 2019). It is not certain if the halophyte-derived biochars have similar characteristics as those from glycophyte feedstock. A few studies have shown that biochar amendment can significantly increase soil CEC, and thus improve soil nutrient retention capacity (Chen et al. 2018; Shi et al. 2019). However, we have little understanding in the roles of halophyte biochar as a soil amendment. It is thus meaningful to investigate the impacts of the halophytederived biochars on soil physicochemical properties.

\section{Conclusion}

The biochars derived from different halophytes had distinct characteristics depending on their anatomical features. The $\mathrm{B}_{\mathrm{SS}}$ had higher sodium salt in ash, while $\mathrm{B}_{\mathrm{PA}}$ was high in specific surface area. The $B_{K F}$ had much negative charge, and a high $\mathrm{CEC}$ value, while $\mathrm{B}_{\mathrm{SA}}$ carried more positive charge and had a high $\mathrm{AEC}_{\mathrm{pH} 3.5}$ value. Compared with biochars derived from glycophytes, the halophyte-derived biochars generally had higher ash and
Table 5 Surface charge parameters of the biochars derived from five halophytes under $500{ }^{\circ} \mathrm{C}$ for $1 \mathrm{~h}$

\begin{tabular}{llll}
\hline Biochar & PZNC & $\begin{array}{l}\mathrm{AEC}_{\mathrm{pH} 3.5} \\
\left(\mathrm{cmol} \mathrm{kg}^{-1}\right)\end{array}$ & $\begin{array}{l}\mathrm{CEC}_{\mathrm{pH} 7.0} \\
\left(\mathrm{cmol} \mathrm{kg}^{-1}\right)\end{array}$ \\
\hline $\mathrm{B}_{\mathrm{SA}}$ & $5.44 \pm 0.02 \mathrm{~b}$ & $16.99 \pm 0.21 \mathrm{a}$ & $6.45 \pm 0.02 \mathrm{~d}$ \\
$\mathrm{~B}_{\mathrm{SS}}$ & $4.26 \pm 0.01 \mathrm{e}$ & $3.80 \pm 0.02 \mathrm{e}$ & $9.89 \pm 0.08 \mathrm{~b}$ \\
$\mathrm{~B}_{\mathrm{KF}}$ & $5.40 \pm 0.01 \mathrm{c}$ & $6.05 \pm 0.03 \mathrm{c}$ & $19.36 \pm 0.13 \mathrm{a}$ \\
$\mathrm{B}_{\mathrm{PA}}$ & $5.59 \pm 0.03 \mathrm{a}$ & $9.30 \pm 0.01 \mathrm{~b}$ & $5.90 \pm 0.01 \mathrm{e}$ \\
$\mathrm{B}_{\mathrm{TC}}$ & $4.88 \pm 0.02 \mathrm{~d}$ & $5.05 \pm 0.01 \mathrm{~d}$ & $7.76 \pm 0.00 \mathrm{c}$ \\
Means & 5.11 & 8.24 & 9.87 \\
\hline
\end{tabular}

The different lower-case letters in the same line represent the significant difference at $p<0.05$ among the different biochars

$P Z N C$ point of zero net charge; $A E C_{p H 3.5}$ anion exchange capacity; $C E C_{p H 7.0}$ cation exchange capacity

lower PZNC value and might have a higher potential value as an acidic soil conditioner.

Acknowledgements This study was supported by the 13th fiveyear project of National Key Technology R\&D Program (No. 2016YFC0501306-02), and implemented at Key Laboratory of Arable Land Conservation (North China), Ministry of Agriculture, Key Laboratory of Plant-Soil Interactions, Ministry of Education, China Agricultural University.

Authors' contributions All authors contributed to the study conception and design. Material preparation, data collection and analysis were performed by Hongyang Xiao, Qimei Lin and Jianzhong Li. The first draft of the manuscript was written by Hongyang Xiao. All authors contributed to the article and approved the submitted version.

Funding This study was supported by the National Key Research and Development Program of China (2016YFC0501306).

Availability of data and materials The datasets analysed during the current study are available from the corresponding author on reasonable request.

Code availability Not applicable. 


\section{Declarations}

Conflict of interest The authors declared that the research was conducted in the absence of any commercial or financial relationships that could be construed as a potential competing interests.

Ethics approval and consent to participate Not applicable.

Consent for publication Not applicable.

Open Access This article is licensed under a Creative Commons Attribution 4.0 International License, which permits use, sharing, adaptation, distribution and reproduction in any medium or format, as long as you give appropriate credit to the original author(s) and the source, provide a link to the Creative Commons licence, and indicate if changes were made. The images or other third party material in this article are included in the article's Creative Commons licence, unless indicated otherwise in a credit line to the material. If material is not included in the article's Creative Commons licence and your intended use is not permitted by statutory regulation or exceeds the permitted use, you will need to obtain permission directly from the copyright holder. To view a copy of this licence, visit http://creativecommons.org/licenses/by/4.0/.

\section{References}

Amoah-Antwi C, Kwiatkowska-Malina J, Thornton SF, Fenton O, Malina G, Szara E (2020) Restoration of soil quality using biochar and brown coal waste: a review. Sci Total Environ 722:137852. https://doi.org/10.1016/j.scitotenv.2020.137852

Calvelo Pereira R, Kaal J, Camps Arbestain M, Pardo Lorenzo R, Aitkenhead W, Hedley M, Macías F, Hindmarsh J, Maciá-Agulló JA. Contribution to characterisation of biochar to estimate the labile fraction of carbon. Org Geochem. 2011;42:1331-42. https://doi. org/10.1016/j.orggeochem.2011.09.002.

Cantrell KB, Hunt PG, Uchimiya M, Novak JM, Ro KS (2011) Impact of pyrolysis temperature and manure source on physicochemical characteristics of biochar. Bioresour Technol 107:419-428. https://doi.org/10.1016/j.biortech.2011.11.084

Chen B, Chen Z (2009) Sorption of naphthalene and 1-naphthol by biochars of orange peels with different pyrolytic temperatures. Chemosphere 76:127-133. https://doi.org/10.1016/j.chemosphere. 2009.02.004

Chen G, Wang X, Zhang R (2018) Decomposition temperature sensitivity of biochars with different stabilities affected by organic carbon fractions and soil microbes. Soil Tillage Res 186:322-332. https://doi.org/10.1016/j.still.2018.11.007

Chen X, Lin Q, Rizwan M, Zhao X, Li G (2019) Steam explosion of crop straws improves the characteristics of biochar as a soil amendment. J Integr Agric 18(007):1486-1495. https://doi.org/ $10.1016 /$ S2095-3119(19)62573-6

Cheng C, Lehmann J, Engelhard MH (2008) Natural oxidation of black carbon in soils: changes in molecular form and surface charge along a climosequence. Geochim Cosmochim Acta 72:15981610. https://doi.org/10.1016/j.gca.2008.01.010

Flowers TJ, Munns R, Colmer TD (2015) Sodium chloride toxicity and the cellular basis of salt tolerance in halophytes. Ann Bot 115:419-431. https://doi.org/10.1093/aob/mcu217

Guo X, Liu H, Zhang J (2019) The role of biochar in organic waste composting and soil improvement: a review. Waste Manag 102:884-899. https://doi.org/10.1016/j.wasman.2019.12.003

Han L, Ro KS, Wang Y, Sun K, Sun H, Libra JA, Xing B (2017) Oxidation resistance of biochars as a function of feedstock and pyrolysis condition. Sci Total Environ 616-617:335-344. https://doi.org/10. 1016/j.scitotenv.2017.11.014

Hassan M, Liu Y, Naidu R, Parikh SJ, Du J, Qi F, Willett IR (2020) Influences of feedstock sources and pyrolysis temperature on the properties of biochar and functionality as adsorbents: a meta-analysis. Sci Total Environ 744:140714. https://doi.org/10.1016/j.scito tenv.2020.140714

Hopkins D, Hawboldt K (2020) Biochar for the removal of metals from solution: a review of lignocellulosic and novel marine feedstocks. J Environ Chem Eng 8:103975. https://doi.org/10.1016/j. jece.2020.103975

Hung C, Tsai W, Chen J, Lin Y, Chang Y (2017) Characterization of biochar prepared from biogas digestate. Waste Manag 66:53-60. https://doi.org/10.1016/j.wasman.2017.04.034

Hussain M, Farooq M, Nawaz A (2017) Biochar for crop production: potential benefits and risks. J Soils Sediment 17(3):685-716. https://doi.org/10.1007/s11368-016-1360-2

Kalinke C, de Oliveira P, Mangrich A, Marcolino Junior L, Bergamini M (2019) Chemically-activated biochar from Ricinus communis L. cake and their potential applications for the voltammetric assessment of some relevant environmental pollutants. J Braz Chem Soc. https://doi.org/10.21577/0103-5053. 20190259

Kavitha B, Reddy PVL, Kim B, Lee SS, Pandey SK, Kim K (2018) Benefits and limitations of biochar amendment in agricultural soils: a review. J Environ Manag 227:146-154. https://doi.org/ 10.1016/j.jenvman.2018.08.082

Lehmann J, Rillig MC, Thies J, Masiello CA, Hockaday WC, Crowley D (2011) Biochar effects on soil biota—a review. Soil Biol Biochem 43:1812-1836. https://doi.org/10.1016/j.soilbio.2011. 04.022

Liu Y, He Z, Uchimiya M (2015) Comparison of biochar formation from various agricultural by-products using FTIR spectroscopy. Mod Appl Sci 9(40):247-256. https://doi.org/10.5539/mas.v9n4p 246

Liu X, Mao P, Li L, Ma J (2018) Impact of biochar application on yield-scaled greenhouse gas intensity: a meta-analysis. Sci Total Environ 656:969-976. https://doi.org/10.1016/j.scitotenv.2018. 11.396

Luo Y, Durenkamp M, De Nobili M, Lin Q, Devonshire BJ, Brookes PC (2012) Microbial biomass growth, following incorporation of biochars produced at $350{ }^{\circ} \mathrm{C}$ or $700{ }^{\circ} \mathrm{C}$, in a silty-clay loam soil of high and low pH. Soil Biol Biochem 57:513-523. https://doi. org/10.1016/j.soilbio.2012.10.033

Mao M, Zhao Z, Wang S, Tian C, Zhang K, Gong J, Zhang Z, Jing W (2019) Biochar yield and physicochemical properties of five halophyte species. Arid Zone Res 36(06):1494-1501. https://doi. org/10.13866/j.azr.2019.06.19

Masud MM, Baquy MA, Akhter S, Sen R, Barman A, Khatun MR (2020) Liming effects of poultry litter derived biochar on soil acidity amelioration and maize growth. Ecotoxicol Environ Saf 202:110865. https://doi.org/10.1016/j.ecoenv.2020.110865

Piash MI, Iwabuchi K, Itoh T, Uemura K (2021) Release of essential plant nutrients from manure- and wood-based biochars. Geoderma 397:115100. https://doi.org/10.1016/j.geoderma.2021.115100

Qadir M, Ghafoor A, Murtaza G (2000) Amelioration strategies for saline soils: a review. Land Degrad Dev 11:501-521. https://doi. org/10.1002/1099-145X(200011/12)11:6\%3c501::AID-LDR405\% 3e3.0.CO;2-S

Rajkovich S, Enders A, Hanley K, Hyland C, Zimmerman AR, Lehmann J (2012) Corn growth and nitrogen nutrition after additions of biochars with varying properties to a temperate soil. Biol Fertil Soils 48:271-284. https://doi.org/10.1007/ s00374-011-0624-7

Shi R, Ni N, Nkoh JN, Li J, Xu R, Qian W (2019) Beneficial dual role of biochars in inhibiting soil acidification resulting from 
nitrification. Chemosphere 234:43-51. https://doi.org/10.1016/j. chemosphere.2019.06.030

Singh B, Singh BP, Cowie AL (2010) Characterisation and evaluation of biochars for their application as a soil amendment. Soil Res 48:516. https://doi.org/10.1071/SR10058

Sohi SP, Krull E, Lopez-Capel E, Bol R (2010) A review of biochar and its use and function in soil. Adv Agron 105(1):47-82. https:// doi.org/10.1016/S0065-2113(10)05002-9

Subedi R, Taupe N, Pelissetti S, Petruzzelli L, Bertora C, Leahy JJ, Grignani C (2015) Greenhouse gas emissions and soil properties following amendment with manure-derived biochars: influence of pyrolysis temperature and feedstock type. J Environ Manag 166:73-83. https://doi.org/10.1016/j.jenvman.2015.10.007

Suliman W, Harsh JB, Abu-Lail NI, Fortuna A, Dallmeyer I, GarciaPerez M (2015) Influence of feedstock source and pyrolysis temperature on biochar bulk and surface properties. Biomass Bioenergy 84:37-48. https://doi.org/10.1016/j.biombioe.2015.11.010

Sun Y, Gao B, Yao Y, Fang J, Zhang M, Zhou Y, Chen H, Yang L (2013) Effects of feedstock type, production method, and pyrolysis temperature on biochar and hydrochar properties. Chem Eng J 240:574-578. https://doi.org/10.1016/j.cej.2013.10.081

Van Soest PJ, Robertson JB, Lewis BA (1991) Methods for dietary fiber, neutral detergent fiber, and non-starch polysaccharides in relation to animal nutrition. J Dairy Sci 74:3583-3597. https:// doi.org/10.3168/jds.S0022-0302(91)78551-2

Ventura Y, Eshel A, Pasternak D, Sagi M (2015) The development of halophyte-based agriculture: past and present. Ann Bot 115:529540. https://doi.org/10.1093/aob/mcu173

Wang X, Zhou W, Liang G, Song D, Zhang X (2015) Characteristics of maize biochar with different pyrolysis temperatures and its effects on organic carbon, nitrogen and enzymatic activities after addition to fluvo-aquic soil. Sci Total Environ 538:137-144. https://doi. org/10.1016/j.scitotenv.2015.08.026

Wu W, Yang M, Feng Q, McGrouther K, Wang H, Lu H, Chen Y (2012) Chemical characterization of rice straw-derived biochar for soil amendment. Biomass Bioenergy 47:268-276. https://doi. org/10.1016/j.biombioe.2012.09.034

Xiao R, Wang P, Mi S, Ali A, Liu X, Li Y, Guan W, Li R, Zhang Z (2019) Effects of crop straw and its derived biochar on the mobility and bioavailability in $\mathrm{Cd}$ and $\mathrm{Zn}$ in two smelter-contaminated alkaline soils. Ecotoxicol Environ Saf 181:155-163. https://doi. org/10.1016/j.ecoenv.2019.06.005

Yan Y, Tian J, Fan M, Zhang F, Li X, Christie P, Chen H, Lee J, Kuzyakov Y, Six J (2012) Soil organic carbon and total nitrogen in intensively managed arable soils. Agric Ecosyst Environ 150:102-110. https://doi.org/10.1016/j.agee.2012.01.024

Yuan J, Meng J, Liang X, Yang E, Chen W (2021) Biochar's leacheates affect the abscisic acid pathway in rice seedlings under low temperature. Front Plant Sci 12:646910. https://doi.org/10.3389/fpls. 2021.646910

Yue Y, Lin Q, Irfan M, Chen Q, Zhao X (2016) Characteristics and potential values of bio-oil, syngas and biochar derived from $\mathrm{Sal}$ sola collina Pall. in a fixed bed slow pyrolysis system. Bioresour Technol 220:378-383. https://doi.org/10.1016/j.biortech.2016. 08.028

Yue Y, Lin Q, Irfan M, Chen Q, Zhao X, Li G (2017) Characteristics and potential values of bio-products derived from switchgrass grown in a saline soil using a fixed-bed slow pyrolysis system. Bioresources 12(3):6529-6544. https://doi.org/10.15376/biores. 12.3.6529-6544

Zhang H, Chen C, Gray EM, Boyd SE (2017) Effect of feedstock and pyrolysis temperature on properties of biochar governing end use efficacy. Biomass Bioenergy 105:136-146. https://doi.org/10. 1016/j.biombioe.2017.06.024

Zhao K, Zhou S, Fan H (2002) Addendum of halophyte species in China. Chin Bull Bot 19(5):611-613. https://doi.org/10.3969/j. issn.1674-3466.2002.05.015

Zhao L, Cao X, Mašek O, Zimmerman A (2013a) Heterogeneity of biochar properties as a function of feedstock sources and production temperatures. J Hazard Mater 256-257:1-9. https://doi.org/ 10.1016/j.jhazmat.2013.04.015

Zhao Z, Zhang K, Wang P, Tian C (2013b) Desalination effect of halophytes in heavily salinized soil of Karamay, Xinjiang, China. J Desert Res 33(05):1420-1425. https://doi.org/10.7522/j.issn. 1000-694X.2013.00207

Zhao L, Zheng W, Cao X (2014) Distribution and evolution of organic matter phases during biochar formation and their importance in carbon loss and pore structure. Chem Eng J 250:240-247. https:// doi.org/10.1016/j.cej.2014.04.053 